\title{
Dispute resolution mechanisms among the Afar People of Ethiopia and their contribution to the Development Process
}

\author{
KA GEBRE-EGZIABHER ${ }^{1}$
}

\begin{abstract}
Disputes are one of the major factors negatively affecting the development process of any nation. They divert resources that could otherwise be used productively; hence, there appears to be general agreement on their undesirability (Alexander 2005). Disputeresolution practices and peace-building mechanisms remain problematic for most societies in the world including those in Africa, as most of them are trying to imitate Western modalities instead of using their own indigenous knowledge systems and skills. The dispute-resolution practices of the ancient Ethiopians in have been established for many thousands of years, and have been used to prevent loss of life and the destruction of property. This paper reveals that the dispute-resolution practices of the Afar people of Ethiopia significantly contributed to the development process. The article reveals that it is difficult to attain development without developing dispute resolution practices and it also shows that it is difficult, though not impossible, to resolve disputes without assuring development by eliminating poverty. Thus, it concludes that the ancient Aksumite, which was one of the first four great civilizations on earth, must have developed a unique type of dispute resolution practices that enabled Ethiopia of that time to be one of the leading countries in the globe during that time. No doubt every nation has its own indigenous dispute-resolution practices. It is thus possible to resolve disputes in by using indigenous knowledge systems, instead of using Western modalities. In this paper, the dispute-resolution practices of the Afar people of Ethiopia are discussed.
\end{abstract}

Keywords: Afar, dispute resolution, Ethiopia, Horn of Africa, indigenous knowledge, peace building, stability

\section{Introduction}

Taking the present situation in Africa, where many countries suffer from disputes of various types, the "Conference on Resolving Disputes in the South African way" which was organized by IDRA (Institute of Dispute Resolution in Africa) held on 5-6 November, 2014 in Pretoria at Kgrong Function Hall, Unisa Main Campus is timely and relevant. There are reports daily that thousands of Africans are suffering from disputes. On the other hand, nowadays, disputes in the African continent are becoming more of a business and way of life to many Western organisations. Until now, Africans have tried to resolve disputes using Western modalities; but practical evidence has already shown that such modalities often

1. Dr Kinfe Abraha Gebre-Egziabher is the Director at the Institute of Population Studies, Mekelle University, Ethiopia. Email: kinfeab@yahoo.com

TD The Journal for Transdisciplinary Research in Southern Africa, 10(3) December 2014, pp. 152-164. 
aggravate the disputes in Africa and do not resolve them. The author thus congratulates IDRA for taking the initiative of organising a problem-solving conference that tries to resolve African disputes in an African way. It is the author's strong belief that dispute-resolution practices are as old as humans. Thus much can be learned from the dispute-resolution practices of the first Ethiopian people, as Ethiopia is a site of human origin.

"All human beings are descendants of Africans" (Henze 2000: 6). But as a result of population dynamics (mainly due to high mortality rates and high rates of emigration that have existed for centuries), it is only at the beginning of the second decade of the 21 st century that the African population rises to one billion. Disputes are one of the factors contributing to the premature death of thousands of Africans almost every year. Thus, it is important to develop mechanisms for resolving disputes in the African way; and it is believed that the dispute-resolution practices of the first people of Ethiopia offer lessons in this regard.

Ethiopia has a strong claim to being one of the oldest countries in the world. Written and pictorial records reveal aspects of its history extending back well beyond 4000 years. Petrography takes it back at least 5,000 years. Archeology and Paleontology bring the country's history back millions of years. Ever since the American Paleontologist Donald Johanson discovered that the skeleton of a twenty-year-old hominid female on 30 November 1974 in a dried up lake bed at Hadar in the Afar Triangle 100 miles Northeast of Addis Ababa, Ethiopia has come into the forefront of regions where mankind is believed to have first evolved. This famous young ape lady whom Johanson called Lucy and gave the scientific name Australopithecus Afarensis (Afar Ape-man), lived more than 3 million years ago (Henze 2000: 1).

Thus, when we talk about the dispute-resolution practices of the first people of Ethiopia, in a way we mean the dispute-resolution practices of the Afar people; though migrations and other elements of population dynamics might have influenced the ethnic compositions of such a people. In any society, disputes are one of the major factors negatively affecting development. They divert resources that could otherwise be used productively; hence, it appears that there is a general agreement that they are undesirable (Alexander 2005). Dispute resolution strategies and peace-building mechanisms remain problematic for most societies in the world, including Africa. The need to develop and sustain a culture of peace has become more important than ever given the scale of destruction and the resilience of disputes.

The Afar National Regional State (ANRS), also known as Region 2, shares international borders with Djibouti and Eritrea and is lies in the north-eastern part of Ethiopia. The total size of the region is $94817 \mathrm{~km}^{2}$. The region is divided into five administrative zones, 32 weredas and 358 kebeles.

The north-eastern part of Ethiopia is one of the centres of ancient civilizations of our planet, the Aksumite civilization being the oldest. "The Persian prophet Mani, who lived in the third century AD, wrote: There are four great kingdoms on earth: the first is the Kingdom of Babylon and Persia; the second is the Kingdom of Rome; the third is the Kingdom of the Aksumites; the fourth is the Kingdom of the Chinese" (Yuri 1979, cited in Henze 2000: 22). From this one can deduce that the dispute-resolution practices of the first people of Ethiopia were effective and a prerequisite to the ancient civilization of the Ethiopians.

Henze (2000) also explains that the area around Aksum would have provided food for a continually expanding urban population during the period of maximum expansion of the empire. According to Henze (2000), in the late 3rd century BC the Aksumites expanded to 
control the trade of the whole Red Sea region. The emperors developed military power to protect their trading interests. Rome and Persia valued these trading connections and respected the power and influence of the Aksumites, and the Persian prophet's inclusion of Aksum among the four great empires of the world was justified. Munro-Hay sums up the justification of the prophet as follows:

As far as the history of civilization in Africa is concerned... Aksum, Egypt and
Meroe ... were the only internationally recognised independent African
monarchies of important power status in its age. Aksumite Ethiopia, however,
differs from the previous two in many ways. Its economy was not based on the
agriculture wealth of the Nile valley, but on the exploitation of the Ethiopian
highland environment and the Red Sea trade; unlike Egypt and Meroe, Axumite
Ethiopia depended for the communication not on ... a great river, but on the
maintenance of considerably more arduous routes across the highlands and steep
river valleys. For its international trade it depended on sea lanes which required
vigilant policing. Most important, Aksum was never to have come into open
conflict with either Rome or Persia, and was neither conquered by these
contemporary powers, nor suffered from punitive expeditions" (Munro-Hay,
cited in Henze 2000: 30),

This may show that the existence of peace and stability was one of the main factors in the ancient civilization and conversely, the civilization also helped to ensure peace and stability. This peaceful coexistence is a reflection of the internal dispute-resolution practices of the first people of Ethiopia in general and the Afar people of Ethiopia in particular.

For a reason that is not well documented in Ethiopian history, the ancient civilization of Ethiopia disappeared and now little is known about it. But most probably the disputeresolution mechanisms of the Ethiopian people of that time were eroded for various reasons which may need further research works and investigations.

The Horn of Africa is home to millions of pastoralists and agro-pastoralists. The region has faced recurrent drought, famine and socio-economic crises, which have led to a decline in the standard of living. Disputes and civil wars have further complicated the life of pastoralists. Wars in the region denied the pastoralists peace, freedom of movement and the freedom to support themselves. With social and political problems added to the existing environmental problems, efforts to enhance the living standard of the pastoralists were delayed and became more complicated. Different forms of dispute that hindered the wise utilisation of the natural resources (mainly the land) in different countries were reasons why the country did not use more than 80 per cent of its resources - including human resources.

According to the Central Statistical Agency (CSA) of Ethiopia, Ethiopia is a multi-ethnic country with over 82 ethnic groups (CSA 2008). These ethnic groups have co-existed peacefully for centuries, perhaps with the exception of struggles for power or occasional clashes due to territorial (land) claims between the neighbouring ethnic groups. Mesfin et al (2007) indicates that there were no wars due to racial, linguistic or religious differences. To the author's knowledge, none of the governments of Ethiopia have clearly reported the nature, magnitude and modes of resolution of ethnic conflicts. As would be expected in any major multi-ethnic, multilingual, multicultural and multi-religious country, some stereotypes of ethnocentrism and misperceptions exist among various ethnic and social groups in Ethiopia. Describing the Ethiopian case, Habtamu (1998: 34) explains: 
Despite the diversities, great similarities exist between the ethnic groups in Ethiopia. Dominant values, outlook to life, the general socioeconomic situation (farming, house construction, etc.), some ethnic friendships and marriages, and existence in one social system for hundreds of years tend to unite and create major similarities between the various peoples. Some degree of commitment to common values and norms is usually needed to maintain social order in a country and this is perhaps the case in Ethiopia.

In fact, there is much room for critical and objective social, historical and socio-economic research on ethnic relations in Ethiopia. Ethnic or national identity is a powerful, sometimes non-rational group attachment that should be handled carefully. Despite the co-existence, tolerance and other common values that the ethnic groups of Ethiopia share, conflicts between different ethnic groups exist; they cause the deaths of thousands of people and hinder the development process. Describing the Ethiopian case, Habtamu (1998: 34) reports that "on the surface, the issue of ethnicity, displacement and national integration look like temporary problems. But, they have deep social and psychological roots and will continue to affect and disrupt the society if not properly understood and dealt with".

Despite the tolerance, co-existence and other shared values of the different ethnic groups of Ethiopia, the intra-group disputes of the Afar ethnic groups has been one of the main problems that the regional and federal governments have tried to address; but they usually use a Westernised approach, which is not effective. Having considered the above major problems and their potential consequences, the need to address disputes using the indigenous knowledge and skill of dispute resolution among the Afar ethnic groups is becoming increasingly urgent.

Ethiopia is a multi-ethnic country with a population of 89 million (CSA 2013). Lowlands occupy over 61 per cent of the land area and are home to over five million pastoralists that belong to diverse cultural groups; the Afar ethnic groups being some of the largest. Pastoralists are those who are highly dependent on livestock eating natural forage for their livelihood, practise a mobile system of land use, and tend to live in areas of low population density. The Afar people are Cushitic-speaking people living in the arid and semi-arid areas of Ethiopia, Eritrea and Djibouti.

\section{Dispute-resolution practices of the Afar People of Ethiopia}

Before looking at the dispute-resolution practices of the Afar People of Ethiopia, it is necessary to define "dispute". In this paper, conflict is defined as a latent dispute between two opposing groups or individuals, or as opposition between two simultaneous but incompatible interests. Thus, dispute is a state of opposition, disagreement or incompatibility between two or more people that may or may not be characterised by physical violence. Disputes are everpresent in human relations and occur at all times and in almost all places. Studies show that there has never been a time or a society in which some individuals or groups did not come into conflict. The first step in resolving disputes is to understand the causes of the particular dispute. But, generally speaking, conflicts arise as a result of differences between rates of change in the moral norms of a society and people's desire, hopes, dissatisfactions and demands.

The dispute resolution of the Afar people of Ethiopia involved elders and clans leaders to solve minor disputes in the context of traditional law; in case of the Afar ethnic groups, this system is called mada'a, which is governed by an unwritten law that is transmitted from 
generation to generation orally. The law is of two types - dispute-resolution laws that concern intra-ethnic group disputes, and laws concerning inter-ethnic group disputes. In the case of the Afar people, the law is called afare when it concerns disputes within the Afar and adanle for those with outsiders. Islamic law (Shari'a) is secondary to traditional law. Almost all ethnic groups have traditional judges.

In Afar ethnic groups, the Muslim judges (kadi) are consulted only for civil affairs like marriage and divorce. Afar tribal law, the mada'a, varies from tribe to tribe and has complex rules. Certain lineages are highly reputed for their knowledge of these dispute-resolution practices Prior cases set precedent and are integrated into the dispute-resolution practices. In the event of major litigation or of a previously unheard-of case, or when the various clan leaders have been unable to impose their judgment on the litigants, an appeal is made to the father of the law (called mada'a abba in the case of the Afar). Most of the time this is a subclan chief (kedo abba) chosen and backed by the elders for his knowledge of the mada'a. When an appeal is made to him in an unprecedented case, he gathers an assembly, the malla, which functions as a legal body to pronounce a brand-new judgment, which in turn will be incorporated into the mada'a.

In case of the Afar ethnic groups, when the father of the law (mada'a abba) is not the kedo $a b b a$, and if the conflict is not resolved, an assembly presided over by the kedo abba is called, which includes the disputants. A decision made at the court level would not have much chance of being enforced in tribal territory without the consent of the kedo abba, unless force were used, something which risks confrontation. A gulub (knee) is a sub-clan and several gulub form a kedo or clan. Each social level is ruled by designated leaders (bura abba, dalla $a b b a$, gulub $a b b a$ and kedo $a b b a$ ) who play a large role in solving internal conflicts and maintaining group cohesion. There is a separation between the judiciary (mada'a $a b b a$ and malla), the legislature (kedo abba, mablo and maquar'a) and the executive (fima and fima abba). Consultation allows agreement to prevail and avoids conflict that would result in division and violence.

The maro institution

For the Afar people, maro is the session held under a tree to resolve conflict when dispute arises. A makaban (judge), the elders, the disputants, witnesses and observers sit in a circle (from which the term maro derives). The makaban is a clan leader (at the confederation level) who knows the customs. Depending on the gravity of the case, the number of makaban may vary from one to ten. Besides, the makaban may select elders who have a good reputation within the community to assist him. Although many of those elected as elders are aged people, a young person who has good integrity and has won the respect of his people may be elected to give such service. Women are excluded from giving service as makaban and elders. The makaban and elders are not required to have formal training. They give this service to their community without any remuneration, although the community gives them food and drink if the disputes they adjudicate take more than a day.

The first people of Ethiopia use dispute-resolution practices to settle disputes that arise within the family, between neighbours, within a clan and between clans. The traditional institution of maro has jurisdiction over every dispute with the exception of disputes relating to marriage, divorce and inheritance, which are left to the Shari'a court, mainly in urban areas. The Afar use this institution to resolve criminal cases that range from insult to homicide and every civil case, without taking into account the amount of money involved. 
The regular civil and criminal courts adjudicate cases arising between settlers from other parts of Ethiopia working in the state, and cases that involve those settlers and the Afar people.

In short, the first people of Ethiopia use dispute-resolution practices that are accessible, cheap and provide justice within a relatively short period of time. This system resolves minor cases like insults within a single day when the accused admits the charge. Although some complicated cases relating to homicide that result in disputes between clans sometimes take up to ten years, the average dispute within a clan usually does not take more than six months to resolve. In the case of the Afar, for example, the makaban continues to serve as a judge indefinitely as long as he does not commit acts that erode the people's confidence on him. He is expected to be impartial, to have a good knowledge of customary law and precedents of traditional/customary decisions throughout his service. About 15-20 sub-clans exist under each major clan. Except for crimes like theft, which come directly to the makaban, all disputes that arise within the sub-clan and between the sub-clans are resolved by the kedo abba of the sub-clans. A disputant dissatisfied by the decision of the kedo abba can appeal to the makaban. The decision of the makaban is final in cases arising within a specific clan.

Inter-clan disputes are brought to the makaban of neutral clans, who resolve the issue supported by elders selected from other clans. Disputes between different clans usually arise from conflict over boundaries. A clan dissatisfied with the decision of the makaban on such issues may appeal to the Sultan, who, after hearing the makaban and the elders, who participated in the decision and the aggrieved party, may maintain, modify or reverse the decision of the makaban. The decision of the Sultan is final and no appeal is available against it in the customary dispute-resolution system. In addition to the above kinds of dispute arising between individuals of the same clan and conflicts between different Afar clans, occasionally conflict occurs inter-ethnic groups bordering Afar territory. These include Tigrean, Amhara, Oromo and Issa and are often over homicide or grazing land. This kind of conflict is usually resolved by establishing a committee of arbitrators composed of elders and government officials from both sides.

\section{Procedures to resolve intra-clan disputes}

Disputes that occur intra-clan usually arise from minor conflicts such as insults and quarrels that may result in bodily injury. Conflict over grazing land and homicide rarely occur between members of the same clan. Any member of a clan who comes across conflict between two or more individuals has the moral obligation to try to reconcile the disputants. If they do not accept the proposal of reconciliation or if the committed crime is grave, the injured party or anyone who witnessed the cause of the dispute can bring the case to the kedo abba of the subclans or the makaban of a clan, depending on the gravity of the case. The makaban to whom the disputants bring their case selects elders who help him in deciding the case and fixes the place and date of hearing the dispute in the maro. After the elders, disputants, witnesses, if any, and observers are gathered under a tree, the makaban opens the proceedings by requesting the disputant to bring a $h a b i$, who guarantees the good behaviour of the disputant and acceptance of the makaban's decision. The habi may be a member of a family or a subclan chief of the disputants.

After the disputants nominate their habisi [plural form] the makaban gives the plaintiff the first opportunity to explain his case. The plaintiff may do this personally or select a representative, usually a chief of his clan, to speak in his name. Children below the age of 15 , or persons who are considered unable to explain their case, are not allowed to give testimony in front of the maro, and must be represented by an elder from their clan or by her husband in 
a case of married woman. Unless he admits the allegation, the defendant or his representative is given the chance to explain their version of the case after the plaintiff completes his presentation.

After hearing both parties, the makaban may give both parties a chance to rebut, if possible, what their opponents say. If there are witnesses named by the plaintiff the makaban asks them to explain what they know about the dispute. If the witness is not present in the maro, the makaban orders him to appear and adjourns the case for other time. The plaintiff or anyone who hears this order informs the witness. The witnesses appear in the maro because they respect the order of the makaban. The people of Afar take it as their religious obligation to give testimony on what they have witnessed and never hesitate to fulfil this duty.

If the defendant has witnesses, he has the right to present them. The plaintiff has the right to cross-examine the testimony of the defendant's witnesses. If no one witnessed the disputed issue brought before the makaban and if the defendant denies the allegation, the makaban asks the defendant to take an oath, which is usually done by putting his hand on the Koran. Before the defendant make an oath the makaban adjourns the case for another day to give family members and clan chiefs a chance to convince the defendant to admit to the allegation, if he did commit the offence. They may go to the extent of promising to make a contribution to the compensation paid to the injured party if the defendant is convicted. If the defendant insists that he is not guilty, he takes the oath and is set free from the allegation.

If the defendant admits the allegation, or after the oral evidence presented by the plaintiff or both parties is heard, the makaban gives any volunteer who attended the proceeding a chance to summarise what was said. After summarising the proceedings and the testimony of witnesses, the speaker may give his opinion on the allegation. After all the above procedures have been followed, the makabans and the elders discuss the case and agree on a decision, taking into consideration the manner in which the offence was committed, notably whether it was intentional, unintentional or negligent. Finally, the makabans pronounce the decision in public and the maro is declared closed by the blessing made by an elder. All the proceedings in the maro are carried out in public without regard to the nature of the dispute and the age of parties. This practice is one of the features that differentiate a maro from procedures applicable in a formal court, which may prohibit a public hearing only in exceptional cases and conduct sessions in camera to protect private lives and public morality.

\section{Procedures to resolve inter-clan disputes}

When conflict occurs between members of different clans, the makaban of one of the disputant clans bring his case to the makaban of a neutral clan before the conflict can cause serious damage; in the case of inter-clan homicide, the intention is to resolve the issue amicably before the clan of the deceased can seek revenge. If the issue is not resolved members of a deceased's clan are duty-bound to kill any member of the offender's clan, including an innocent person, in vengeance. A prominent personality whose death would hurt the clan of the offender is usually selected as the victim.

The makaban of the neutral clan announces to both parties the date of the hearing and orders both parties not to take any measures that can harm the amicable resolution of the case. Both parties, and members of the injured clan, are expected to refrain from taking vengeance and respect the words of the makaban. Depending on the gravity of the case, the makaban may ask the help of other makabans of different (neutral) clans and select elders from different clans to 
resolve the dispute brought to him. Makabans of disputant clans represent their clans and explain their version of the disputed issue to the makabans of the neutral clan. After this the dispute goes through the procedures employed to resolve intra-clan disputes.

Substantive rules applied and remedies available under the maro

The customary mada'a passes from generation to generation orally. The makaban and elders who are elected to resolve disputes are expected to know the mada'a and how it is applied. The late Fitwarari Yasin Mohammad made efforts to put these laws in writing; Afar Customary Law (Mahomed 1973: 7) is based on information he collected from the memories of the Afar elders to preserve the mada'a for future generations. The mada'a classified criminal acts into five types, namely: 1) crime against life; 2) crime against the body; 3) crime against property, 4) crime related to adultery and 5) crime of insult. Besides, the mada'a mentions vengeance and compensation as modes of remedy or penalties for offences committed. Disputes are resolved without reference to written rules and rely on memories of previous decisions (precedents) and knowledge of Afar mada'a.

Remedies available under the mada' $a$ are vengeance and different amounts of compensation, depending on the nature of the dispute. Vengeance is ordered in rare cases when a person who commits a murder disappears and the case is heard in his absence. In this exceptional situation the makaban may take a decision that allows members of the clan of the deceased to take revenge, but only against the murderer. Although there is no clear rule that allows capital punishment under this kind of decision implicitly allows members of the deceased clan to kill the murderer. The clan of the offender usually accepts such a decision to avoid vengeance being taken on its other members. Although the mada'a uses goat kids as standard measures of compensation, which may be convertible to money or other livestock, elders state that in most Afar areas cattle are the standard used to measure the amount of compensation. The maximum amount of compensation is 100 camels for the intentional murder of a man. If this murdered person is a woman, 50 camels are awarded as compensation. The lowest compensation is a cow for the offence of insult. The compensation given in cattle or camels is convertible to money in many areas.

The amount of compensation payable in case of bodily injury is fixed after examining the injured part. In cases where a scar is left on the body of the injured, its length and depth are measured by using fingers to decide the amount of compensation. Mada'a has fixed penalties, with a gradation for any kind of bleeding: the loss of one finger costs 10 silver coins, a thumb is considered as four fingers which costs 40 silver coins and a hand costs 500 silver coins. Cash payment was introduced under the Italian occupation, with a cow equivalent to 12 silver thalers. The customary rules and procedures applied in resolving the dispute are the same in all Afar areas, though the amount of compensation differs slightly from place to place. After fixing the amount of compensation the makaban may reduce the amount by up to 10 per cent to create an opportunity for reconciliation between the disputants.

The injured party may collect only part of the compensation to re-establish good relations with the offender or his clan. This practice is widely accepted and indicates that the amount of compensation pronounced at the judgment is nominal and reducible to a lower amount for the sake of reconciliation.

\section{Execution of the decision}

Unlike in modern justice systems, traditional dispute resolution usually lacks the machinery to enforce judgments unless the disputant voluntarily accepts the penalty imposed. In Afar 
society the family of the offender or his clan members, who guarantee that the decision of the makaban will be carried out, persuade the offender to pay the compensation. In many cases members of the offender's clan contribute money or cattle for payment of compensation if the offence committed was grave and many cattle are payable in compensation. The clan may ostracise a member if he refuses to respect the decision of the makaban. In the case of decisions regarding disputes between different clans, the execution of the decision is guaranteed by fear of further killings between clans and the complete acceptance of its ruling by all parties concerned. This indicates that under this system social sanction is at the centre of the decision-enforcement mechanism, and ostracism is very common.

The fima constitutes a social institution capable of providing sanctions to ensure peaceful outcomes, together with the above maro, without referring to legal governmental authorities. The power of its leader, the fima $a b a$ can thwart that of the clan elders. The fima is responsible for implementing a judgment and ensuring the penalties are paid. The solidarity of the fima towards its members is exercised both at the time of the physical failings and following events causing significant expenditure (such as marriage and burial), similar to the role of customary credit associations (ikub). The fima can also intervene when the herd of a member is decimated by drought; it answers the need of individuals for protection against disasters and shocks and thereby plays a role in social welfare. The fima has some regional variants. In Tadjourah (Djibouti), the system is based on age classes; in the Awsa, it is related to land ownership, and other varieties are related tribal membership within geographical areas. The fima thus provides protection and defence; it also offers mutual help and constitutes a strong social institution.

\section{Dispute resolution practices and their contribution to the Development Process}

"Development is a concept that has become to define both our identity and the direction of the arrow of time ... .Development is also now closely tied to the controversial concepts of the First, Second and Third Worlds" (Hoppers and Richards 2011:13). The Environmental Protection Authority of Ethiopia (EPA) has also defined the concept development as follows:

Development is a broad concept that has many components with it. Development
is a change in society's economic, cultural, institutional and political life. A change
in one aspect of these development ingredients also does not make any difference
unless supported by the others. Development has to deal with the allocation of
available resources, which should not be misused or corrupted; and should consider
the economic, social, political and institutional situations of a certain country
(EPA, 2008: 7).

There are so many indicators of development. As explained by EPA (2008: 7), some of the indicators of development are:

1. Raising peoples' living standard; their income and consumption levels of food, medical services, education, etc. through relevant economic growth processes. This encompasses all the socioeconomic indicators that help to enhance their wellbeing between two points in time.

2. Creating conditions conducive to the growth of peoples' self-stream through the establishment of social, political and economic systems and institutions that promote human dignity and respect; and 
3. Increasing people's freedom by enlarging the range of their choice variables, as by increasing varieties of consumer goods and services.

One can easily understand that such a development is not attainable without peace and stability. Thus, dispute resolution has to be considered as a precondition for any type of development. On the other hand, if there is no sustainable development, it becomes difficult to have peace and stability. Hence, the indigenous knowledge systems and skills that the Afar people are practicing in resolving disputes has to be considered as one main strategy in the development process of the nation.

\section{Conclusion and recommendations}

Although the customary system has some weaknesses relating to the violation of human rights, the Afar people prefer its services because it is cheap, accessible, gives the people the chance to participate in the process and emphasises reconciling the feuding parties, rather than punishing the offender. Especially when the dispute involves conflict between clans, the government usually requests the help of these customary institutions to resolve cases instead of using the formal justice system. Although the customary system makes a considerable contribution to keeping law and order in the state, it has not obtained legal recognition under national law. To bridge this gap between practice and the law, the House of Peoples' Representatives and the Afar State Council should officially recognise this customary dispute-resolution mechanism, and should consider the implications of limiting its jurisdiction to personal and family issues according to Article 34 (5) of the FDRE Constitution (FDRE 1995). This would be important in raising the awareness of the Afar people, especially those who serve as makaban and elders. However, before the government recognises the maro and decides on the limits of its jurisdiction, it must strengthen the efficiency of the formal justice system to handle criminal cases that arise between individuals and clans. The overall aim of this paper is to present the dispute-resolution practices of the ancient Aksumite civilization of Ethiopia by taking the Afar people as a case study. The author suggests that the following points need to be considered so that disputes can be resolved in an African way and sustainable development can be ensured.

1. Dispute resolution is a very expensive process, mainly when addressed using imported knowledge and skills. The best strategy is to prevent conflicts before they occur. In Ethiopia, clear strategies of dispute prevention must be developed, discussed and then implemented. Such dispute-prevention and dispute-resolution mechanisms must be based on the indigenous knowledge of the people and be included in the elementary school curriculum. The subjects must be taught by well-trained teachers, which implies that the nearby universities must create such programmes. In this regard, one of the centres that the Institute of Population Studies at Mekelle University has is a Centre for Dispute Resolution. The support that it receives from IDRA is of paramount importance.

2. It is obvious that development is the best mechanism for preventing and resolving conflicts. Hence, continued efforts must be exerted to ensure development in Ethiopia in general and the Afar Regional State in particular. All stakeholders working in Ethiopia should focus their efforts on the development processes of the nation so that peace and stability can be sustained.

3. In Africa, disputes have become a way of life for many international organisations. As a result, instead of focusing on strategic and long-term solutions, many international 
NGOs are focusing on short-term solutions; and some may even play a role in aggravating the disputes. It is now time to rethink the issue and then give long-lasting solutions by taking the main causes of the disputes into account and resolving disputes in an African way (using the indigenous knowledge systems of dispute resolutions).

4. It is obvious that the traditional leadership and the modern governance system will co-exist and have their own roles in both the development process and the dispute resolving strategies. Hence, both leadership styles will have their own role in either aggravating or resolving disputes between two ethnic groups. It is recommended that the best practices of the two leadership styles (the indigenous and the Western) be harmonized so that there will be no gap between them. This demands an attitudinal change in the leadership of both sides, so that they keep an open mind and learn from each other.

5. The dispute-resolution process has to ensure the participation of all stakeholders and those who are affected by the conflict. The leadership at all levels must devise mechanisms that ensure the participation of the general public by developing and institutionalizing the indigenous knowledge and practices of dispute resolution.

6. As educational levels increase, the probability that people may create conflict decreases. But this decrease also depends on the quality and relevance of the education delivered. Hence, due attention must be given to enhancing the quality and relevance of the educational system, from elementary schools to university level.

7. As disputes arise in the African continent, different groups which have vested interests get involved in aggravating the magnitude and extent of the dispute. Hence, the involvement of such groups with vested interests needs due attention; mainly by the people who may suffer from the consequences of such disputes.

8. Like the Afar people of Ethiopia, almost all African countries have their own indigenous knowledge and practices of dispute resolution. It is time to harmonise these by taking the best practices and the common ones so that common, agreedupon and harmonised indigenous knowledge and methods of conflict resolution are available to African countries, which can then implement them in resolving the conflicts between them. Thus, it is time to resolve disputes in the African way.

\section{References}

Alexander, Atilo (2005). Geo-political explanations of conflict in the Horn of Africa. Addis Ababa: Addis Ababa University Printing Press.

Barth, Frederik (1994). Introduction, in Frederic Barth, (ed.) Ethnic Groups and Boundaries: The social organization of culture difference. Oslo: Pensumtjeneste: 1-11.

Beiberaj, Elez (1998). Yugoslavia: a continuing crisis? Conflict Studies 225: 15 - 17.

Brown, Michael E. (1997). Causes and implications of ethnic conflict, in Montserrat Guibernau and John Rex, (eds). The ethnicity reader: Nationalism, multiculturalism, and migration. Cambridge: Polity Press: 80-100. 
Chazan, Naomi et al. (1992). Politics and Society in Contemporary Africa. Second Edition. Boulder, Colorado: Lynne Reiner Publishers.

Cohen, R. (1978). Ethnic problems and focus in Anthropology. Annual Review of Anthropology 17: 12 - 14.

Collier, P. (2000). Economic causes of civil conflict and their implications for policy: A forthcoming chapter, in Chester A. Crocker and Fen Osler Hampson with Pamela All (eds). Managing global chaos. Washington DC: US Institute of Peace.

CSA (1995). Population and Housing Census of Ethiopia. Results of Tigray Region. Central Statistical Authority of Ethiopia. Addis Ababa.

CSA (2013). Statistical Abstract of Ethiopia. Central Statistical Authority of Ethiopia. Addis Ababa.

Development Planning and Research Department (DPRD), Ministry of Finance and Economic Development (MoFED) (2005). Ethiopia: Sustainable Development and Poverty Reduction Program (SDPRP). Annual Progress Report of 2003/04. Addis Ababa: DPRD \& MoFED.

EPA. 2008. Ethiopia environment outlook: Environment for development. The Federal Democratic Republic of Ethiopia, Addis Ababa.

Eriksen, Thomas H. (1997). Ethnicity, race and nation, in Monsterrat Guibernau and John Rex (eds). The ethnicity reader: Nationalism, multiculturalism and migration. Cambridge: Polity Press: 33-42.

FDRE (1995). The Constitution of the Federal Democratic Republic of Ethiopia. Berhanena Selam Printing Press. Addis Ababa.

Getachew, Kassa (2001). Resource Conflicts among the Afar of North-East Ethiopia, in M. Salih Diez and M. Ahmed (ed). conflict institutions and government. Addis Ababa: OSSREA.

Henze, P.B. 2000. The layers of time: A history of Ethiopia. Hurst \& Company, London.

Habtamu, Wondimu (1998). Ethnicity, displacement and national integration: three pronged challenges to Ethiopia. Addis Ababa University: IER Flambeau 6(1). December 1998.

Kelemework, T. (2010). Conflict and Peace-Making in Northern Afar, Ethiopia: Perceptions, Views and Practices. Paperback - Sptember 1, 2010.

Laremont, Ricardo Rene, ed. (2002). The causes of war and the consequences of peacekeeping in Africa. Portsmouth, NH: Heinemann.

Markakis, J. (2004). Ensuring the sustainability of pastoralism in East Africa. Minority Rights Group $\quad 2004 . \quad$ Available at http://minorityrights.org/admin/Download/pdf/MRG-PastoralistsRpt.pdf (accessed on 23 October, 2014)

Mesfin, Yilma and Bantayehu (2007). Dealing with large-scale violence! Is comprehensive academic training needed? Paper on Conflict Resolution prepared for a Workshop organised by APCMC on behalf of Initiative Africa: 18 July 2013, Addis Ababa.

Odora Hoppers, C.A. \& Richards, H. 2011. Rethinking thinking: Modernity's "other" and the transformation of the university. University of South Africa, Pretoria. 
Nicholas, G. (1967). Sociological Theory: its nature and growth. New York: Random House.

Nhema, Alfred G. ed. (2004). The quest for peace in Africa: Transformations, democracy and Public Policy. Addis Ababa International Books with OSSREA.

Nhema, Alfred and Paul Tiyambe Zelez (2008). The roots of African conflicts: the causes and costs. Pretoria: Unisa Press.

Norman U, J.E. Milton and K. Anirudh (1998). Reasons for success. Learning from instructive experience in rural development. New Delhi: Kumarian Press.

Smith, Anthony D. (1997). Structure and persistence of ethnic dispute, in Montserrat Guibernau and John Rex (eds). The ethnicity reader: nationalism, multiculturalism and migration. Cambridge: Polity Press: 27-33.

Victor, A.O. Adetula (2008). The role of sub-regional schemes in conflict prevention and management in Africa. A Framework for a Working Peace System.

Vanhanen, Tatu (1999). Domestic ethnic conflict and ethnic nepotism: A comparative analysis. Journal of Peace Research 36(1): 55-73.

Vidya, B. and Sachdeva, D.R. (1996). An Introduction to Sociology. Allahabad: Kitab Mahal. 